ISSN = 1980-993X-doi:10.4136/1980-993X
www.agro.unitau.br/ambi-agua
E-mail: ambi-agua@agro.unitau.br
Tel.: (12) 3625-4116

\title{
Water balance in Cubatão-Sul river catchment, Santa Catarina, Brazil
} (doi:10.4136/ambi-agua.38)

\author{
Masato Kobiyama; Pedro Luiz Borges Chaffe \\ Department of Sanitary and Environmental Engineering, Federal University of Santa Catarina \\ Caixa Postal 476, Florianópolis-SC, CEP88040-900, Brasil \\ E-mail: kobiyama@ens.ufsc.br, chaffe@ens.ufsc.br
}

\begin{abstract}
The objective of the present study was to evaluate the water balance in the Cubatão-Sul river catchment $\left(403.83 \mathrm{~km}^{2}\right)$, Santa Catarina State, Brazil, which is very important for irrigated horticulture and drinking-water supply to the Great Florianópolis Region. The daily data obtained from the Poço Fundo hydrometeorological station and São José Meteorological station during the period between 1977 and 1994 were used for the analysis. A lumped and storage model HYCYMODEL was used for both water balance and evapotranspiration analyses and five additional methods were used for the evapotranspiration analysis. The results from the HYCYMODEL showed that the total discharge and the evapotranspiration in the catchment are approximately $62 \%$ and $44 \%$ of the annual rainfall $(1563 \mathrm{~mm})$, respectively. The total discharge consists on the direct runoff of $26 \%$ and the base flow of $74 \%$. The actual evapotranspiration estimated with the water budget method was practically equal to that obtained with the HYCYMODEL. And the values of the ratio of the annual actual evapotranspiration to the annual potential evapotranspiration are $0.39,0.58,0.65$ and 0.69 for Hamon method, modified Penman method, Blaney and Criddle method and Thornthwaite method, respectively. The increasing rate of the discharge over rainfall is larger than that of the evapotranspiration. When the annual rainfall is more than $930 \mathrm{~mm}$, the discharge is always larger than the evapotranspiration.
\end{abstract}

Keywords: Water balance; evapotranspiration; Cubatão-Sul river.

\section{Balanço hídrico na bacia do rio Cubatão-Sul, Santa Catarina, Brasil}

\section{RESUMO}

O objetivo do presente estudo foi avaliar o balanço hídrico na bacia do rio Cubatão-Sul (403,83 km²), Santa Catarina, Brasil, que é muito importante na irrigação e suprimento de água potável para a Região da Grande Florianópolis. Os dados diários de 1977 a 1994 usados na análise foram obtidos da estação hidrometeorológica do Poço Fundo e da estação meteorológica de São José. O modelo hidrológico concentrado HYCYMODEL foi usado para fazer o balanço hídrico e a análise de evapotranspiração. Outros cinco métodos também foram usados apenas para análise de evapotranspiração. Os resultados do HYCYMODEL mostraram que a vazão total e a evapotranspiração na bacia correspondem a aproximadamente $62 \%$ e $44 \%$ da chuva total média anual (1563 mm). A vazão total é dividida em aproximadamente $26 \%$ de escoamento direto e $74 \%$ de vazão de base. A evapotranspiração real estimada com 0 método do balanço hídrico foi praticamente igual à estimada com o HYCYMODEL. Os valores da razão da evapotranspiração real anual com a evapotranspiração potencial anual são de 0,39, 0,58, 0,65 e 0,69 para os métodos de Hamon, Penmand, Blaney e Criddle e o método de Thornthwaite, respectivamente. A taxa de aumento da vazão com a chuva é maior do que o 
da evapotranspiração. Quando a chuva anual ultrapassa $930 \mathrm{~mm}$, a vazão é sempre maior que a evapotranspiração.

Palavras-chave: Balanço hídrico; evapotranspiração; rio Cubatão-Sul.

\section{INTRODUCTION}

The hydrologic cycle consists in the hydrological processes that are mainly precipitation, runoff, evapotranspiration and soil-water storage. Each process must be evaluated by considering the interrelations among them. The estimation of evapotranspiration is relatively more difficult and complicated than those of precipitation and runoff. That is the reason why various methods have been proposed for the measurement and estimation of the evapotranspiration (Brutsaert, 1982; Pereira et al., 1997). The evapotranspiration estimation is very important in water resource management for hydroelectric power, drinking-water supply, irrigation, and fishery.

Evapotranspiration research is also connected with environmental concerns. While land cultivation extent has been increasing due to population growth, the environment has been degraded due to poor land development planning. Land use and land cover types influence the evapotranspiration mechanism that is characterized by water and heat transport, and consequently contribute to local and global climate change.

Thus, there is a social demand for catchment-level evapotranspiration research to account for water and environmental resources' impacts. This type of research can be better implemented based on water balance analysis that includes all the components of the hydrological processes.

Therefore, the objective of the present study was to evaluate the water balance in the Cubatão-Sul river catchment, Santa Catarina State, Brazil with emphasis on the evapotranspiration. This catchment is very important for irrigated horticulture and drinkingwater supply to the Great Florianópolis Region (Kobiyama and Oliveira, 1999).

\section{MATERIAL AND METHODS}

\subsection{Study area and hydrometeorological data}

The Cubatão-Sul watershed covers an area of $738 \mathrm{~km}^{2}$. Cubatão-Sul river catchment (CSRC) area studied covers $403.83 \mathrm{~km}^{2}$ and lies approximately between latitudes $27^{\circ} 35^{\prime} \mathrm{S}$ and $27^{\circ} 54^{\prime} \mathrm{S}$ and between longitudes $48^{\circ} 47^{\prime} \mathrm{W}$ and $49^{\circ} 03^{\prime} \mathrm{W}$, with altitudes varying from 100 to $1150 \mathrm{~m}$ (Figure 1). Poço Fundo hydrometeorological station (latitude $27^{\circ} 40^{\prime} \mathrm{S}$ and longitude $48^{\circ} 47^{\prime} \mathrm{W}$ ) is located at the middle of the Cubatão-Sul river basin toward the upper stream area of the watershed., The regional climate type is Cfa (humid subtropical with hot summer) according to Köppen classification. The natural vegetation is Atlantic Forest, dominated by Octea catharinensis (canela-preta), Octea pretiosa (canela sassafrás) and Aspidosperma olivaceum (pérola vermelha) species (Santa Catarina, 1986). The bedrock in the CSRC is granite, gneiss and sedimentary rock (Silva and Bortoluzzi, 1987).

The daily discharge and rainfall data from the Poço Fundo station for the period 19771994 were provided by the Empresa de Pesquisa Agropecuária e Extensão Rural de Santa Catarina S.A. (EPAGRI) and used for the water balance analysis. At the São José Meteorological station, which is about $20 \mathrm{~km}$ northeast from the Poço Fundo station, EPAGRI collects other meteorological parameter measurements: temperature $\left({ }^{\circ} \mathrm{C}\right)$, relative air humidity (\%), wind velocity $(\mathrm{km} / \mathrm{h})$ and daylight hours (h) that were also used for the evapotranspiration analysis. 


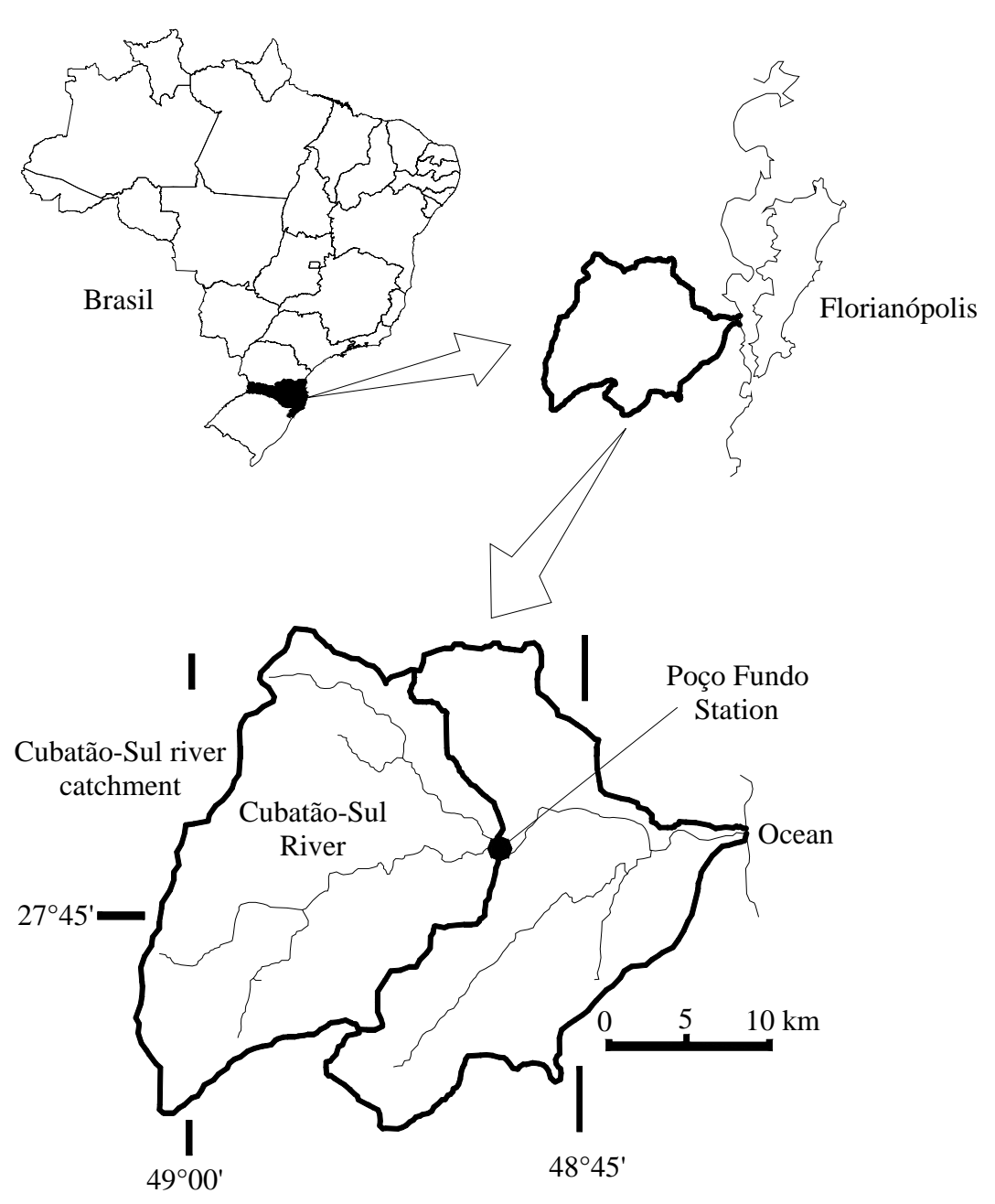

Figure 1. Location of the Cubatão-Sul river catchment area.

\subsection{Application of HYCYMODEL for annual water balance}

The HYCYMODEL proposed by Fukushima (1988) is a lumped and storage model. The model consists of 5 tanks related to the hillslope-channel system (Figure 2). A detailed description of the model can be seen in Fukushima (1988). A brief description follows:

With the ratio of impermeable area $(C)$, rainfall is divided into the channel rainfall $R_{c}(t)$ and the gross rainfall $R_{g}(t)$ where $t$ is the time. Tank I shows the interception process which is defined as:

$$
R_{n}(t)=A G \cdot R_{g}(t)-A I
$$

where $R_{n}(t)$ is the net rainfall and $A G$ and $A I$ are the interception parameters. The interception $E_{i}(t)$ is the difference between $R_{n}(t)$ and $R_{g}(t)$. Since $D_{16}$ and $D_{50}$ are defined as the effective top-soil depths in which the ratios of the contributing area are equivalent to $16 \%$ and $50 \%$, respectively, the standard deviation is:

$$
\sigma=\log \left(\frac{D_{50}}{D_{16}}\right)
$$


The variable $\xi$ is:

$$
\xi=\frac{\log \left\{\frac{\left[S_{u}(t-1)+R_{n}(t)\right]}{D_{50}}\right\}}{\sigma}
$$

Thus, the ratio of the contribution area is expressed by:

$$
m=\int_{-\infty}^{\xi} \frac{1}{\sqrt{2 \pi}} \exp \left(-\frac{\xi^{2}}{2}\right) d \xi
$$

Finally, the effective rainfall $R_{e}(t)$ can be determined with the storage $S_{u}(t-1)$ in Tank II and the net rainfall, i.e.:

$$
R_{e}(t)=m \cdot R_{n}(t)
$$

Tank III, IV and V represent the groundwater system, the subsurface water system and the channel system which determine the base flow $Q_{b}(t)$, the subsurface flow on hillslope $Q_{h}(t)$ and the direct runoff in channel $Q_{c}(t)$, respectively. In Tank II, III, IV and V, the relationship between the storage $S$ and the discharge $Q$ is expressed with the storage function:

$$
S=K \cdot Q^{P}
$$

where $K$ and $P$ are the storage function parameters. For Tanks II, III, IV and V, $K$ and $P$ are defined $K_{u}$ and $P_{u}, K_{b}$ and $P_{b}, K_{h}$ and $P_{h}$ and $K_{c}$ and $P_{c}$, respectively. As Tanks IV and V form the direct runoff, the values of $P_{h}$ and $P_{c}$ are 0.6. As Tank II has the linear phenomenon, the value of $P_{u}$ is 1.0. Following the suggestion of Fukushima (1988), the value of $P_{b}$ is 0.1 .

The transpiration ratio is:

$$
E_{t}(t)=\operatorname{Delta}\left\{P_{t a}+P_{t b} \cdot \sin \left[30^{\circ}-(I-I G)\right]\right\}
$$

where Delta, $P_{t a}, P_{t b}$ and $I G$ are the parameters and $I$ is the monthly number ( 1 to 12 ) corresponding to January to December. Transpiration during a drought decreases when the storage of Tank II smaller than $S_{b c}$. The critical discharge for transpiration $Q_{b c}$ corresponds to $S_{b c}$. The evapotranspiration $E(t)$ is the sum of $E_{i}(t), E_{t}(t)$ and the channel evaporation $E_{c}(t)$. 


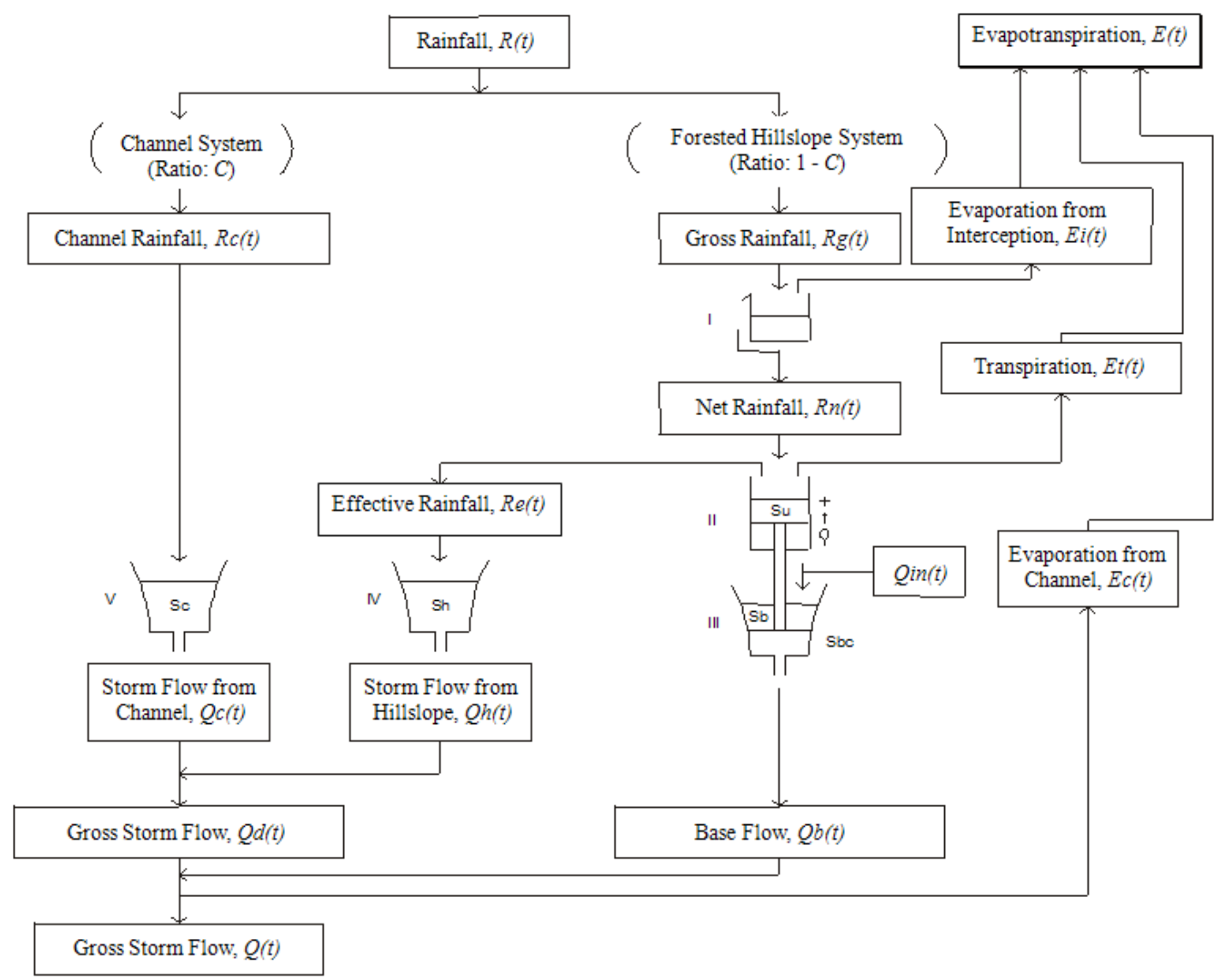

Figure 2. Flowchart of HYCYMODEL. Source: Fukushima (1988).

Kobiyama and Duarte (1997) running a simulation of 11-years hydrograph for the period 1974-1984 ascertained the applicability of this model for the rainfall-runoff processes of the Cubatão-Sul catchment and proposed the parameter values listed in Table 1. The present study used the same values for the parameters and simulated the water balance for the period 1977-1994. For the annual water balance analysis, the following equation was used:

$$
P=E+Q+d S
$$

where $P$ is the rainfall; $E P$ is the evapotranspiration; $Q$ is the discharge; and $d S$ is the change of soil-water storage. By the nature of the HYCYMODEL, EP consists of evaporation due to interception $E_{i}$, transpiration $E_{t}$ and the evaporation from the channel $E_{c}$.

Table 1. Values of the model parameters for the Cubatão-Sul catchment.

\begin{tabular}{cccccc}
\hline Parameter & Value & Parameter & Value & Parameter & Value \\
\hline$C$ & 0.030 & $K_{h}$ & 28 & $A l$ & 1.872 \\
$D_{10}$ & 10 & $K_{c}$ & 2 & $P_{t a}$ & 39 \\
$D_{50}$ & 66 & $P_{b}$ & 0.1 & $P_{t b}$ & 15 \\
$K_{u}$ & 20.1 & $Q_{b c}$ & 1.30 & $I G$ & 10 \\
$K_{b}$ & 4294 & $A G$ & 0.964 & Delta & 1 \\
\hline
\end{tabular}

Source: Kobiyama and Duarte (1997). 


\subsection{Estimation of evapotranspiration}

To estimate the catchment evapotranspiration 6 methods were applied: water budget method, Thornthwaite (1948) method, Hamon (1961) method, modified Penman method (Doorenbos and Pruitt, 1977), Blaney and Criddle (1966) method, and the HYCYMODEL.

The equation for the water budget method is:

$$
E=P-Q
$$

where $E P$ is the actual evapotranspiration in $\mathrm{mm} / \mathrm{month}, P$ is the precipitation in $\mathrm{mm} / \mathrm{month}$, and $Q$ is the runoff in $\mathrm{mm} / \mathrm{month}$. The change of water storage in the catchment during one month was neglected.

Thornthwaite (1948) proposed the following equation:

$$
E P^{*}=16(10 t / I)^{a}
$$

where $E P^{*}$ is the non-revised potential evapotranspiration in $\mathrm{mm} / \mathrm{month}, t$ is the mean monthly temperature in ${ }^{\circ} \mathrm{C}, \quad a$ is a constant $\quad\left(=0.000000675 I^{3}\right.$ $\left.0.0000771 I^{2}+0.01792 I+0.49239\right)$, and $I$ is the Thornthwaite's temperature efficiency index, being equal to the sum of 12 monthly values of heat index $i=(t / 5)^{1.514}$. Then this author used this value to compute the correct value with the following equation:

$$
E P=C_{1} \times E P^{*}
$$

where $E P$ is the potential evapotranspiration in $\mathrm{mm} / \mathrm{month}$ and $C_{1}$ is the correction factor which can be calculated based on UNESCO (1982) (Table 2).

Table 2. $C_{1}$ values for the Cubatão-Sul river catchment.

\begin{tabular}{ccccccccccccc}
\hline Month & Jan & Feb & Mar & Apr & May & Jun & Jul & Aug & Sep & Oct & Nov & Dec \\
\hline$C_{1}$ & 1.19 & 1.02 & 1.06 & 0.95 & 0.93 & 0.86 & 0.91 & 0.97 & 1.00 & 1.11 & 1.13 & 1.20 \\
\hline
\end{tabular}

Hamon (1961) pointed out that the Thornthwaite method overestimated the evapotranspiration in the summer and underestimated it in the winter and proposed the following equation:

$$
E P=1.4(n / 12)^{2} P t
$$

where $n$ is the daylight hours; $P t$ is the absolute humidity in $\mathrm{g} / \mathrm{m}^{3}$.

Doorenbos and Pruitt (1977) modified the Penman (1948) method and proposed a new equation:

$$
E P=C_{2}\left[W \cdot R A_{n}+(1-W) \cdot f(u) \cdot\left(e_{a}-e_{d}\right)\right]
$$

where $C_{2}$ is the correction factor; $W$ is the weighing factor related to a temperature; $R A_{n}$ is the net radiation in $\mathrm{mm} / \mathrm{day} ; f(u)$ is the function of the wind; $e_{a}$ is the saturation vapor pressure at the mean air temperature in $\mathrm{mmH}_{2} \mathrm{O}$; and $e_{d}$ is the saturation vapor pressure at mean dew point in $\mathrm{mmH}_{2} \mathrm{O}$. 
Villela and Mattos (1975) modified the equation of Blaney and Criddle (1966) with respect to the units:

$$
E P=(m t-0.5 T) p
$$

where $m t$ is the monthly mean temperature in ${ }^{\circ} \mathrm{C} ; T$ is the mean annual temperature in ${ }^{\circ} \mathrm{C} ; p$ is the percentage of the monthly daylight hours on the annual daylight hours.

The hydrometeorological data observed at Poço Fundo and São José stations during the period 1977-1994 were used for the evapotranspiration analysis.

\section{RESULTS AND DISCUSSION}

\subsection{Annual water balance}

Figure 3 shows the components of the total discharge. Due to the lack of hydrological data, the year 1991 was not considered in this study. Direct runoff and base flow for the period 1977-1994, related to the total discharge and based on mean values, are $26 \%$ and $74 \%$, respectively. This value for the base flow is in accordance with the value obtained by Hewlett (1982) who stated that about $70 \%$ of the total discharge is usually base flow in mountainous regions. Considering the direct runoff, the components from hillslope and channel are 81\% and $19 \%$, respectively.

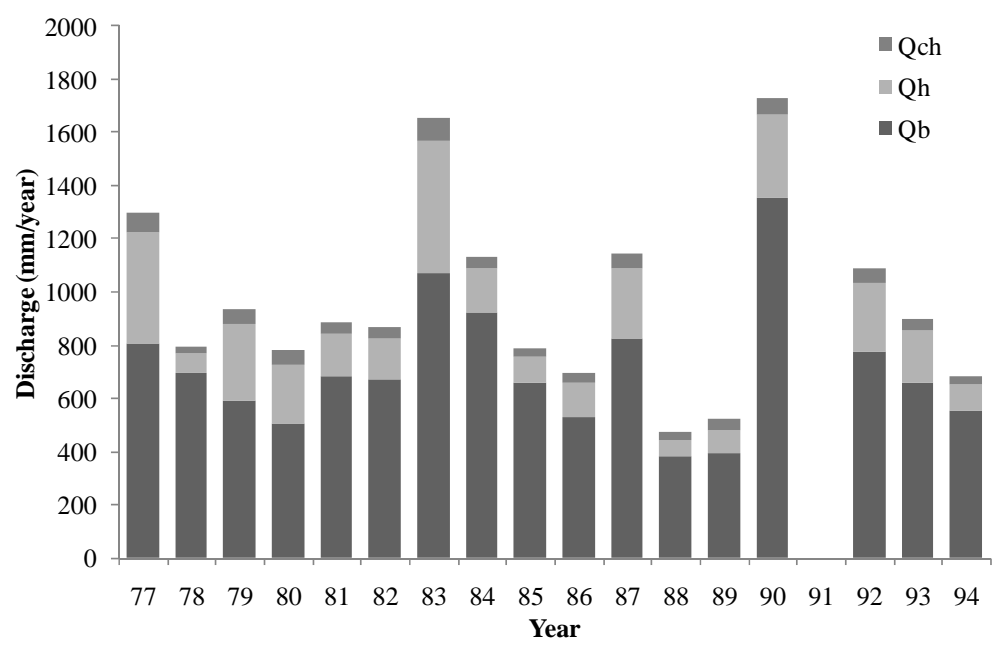

Figure 3. Components variation of total discharge for the period of 1977 to 1994 . $\left(Q_{b}=\right.$ base flow, $Q_{h}=$ direct runoff from hillslope, $Q_{c h}=$ direct runoff from channel).

Transpiration, evaporation by interception, and evaporation from the river to the total evapotranspiration values are 65\%, 33\% and 2\% for the period 1977 to 1994, respectively (Figure 4). According to Fujieda et al. (1997), the annual mean value of the transpiration is equal to that of the evaporation by interception in the Serra do Mar, São Paulo State. Comparing to this result, the ratio of transpiration in the CSRC is larger. It implies that, if the forest area is reduced in the CSRC the total discharge will increase significantly. 


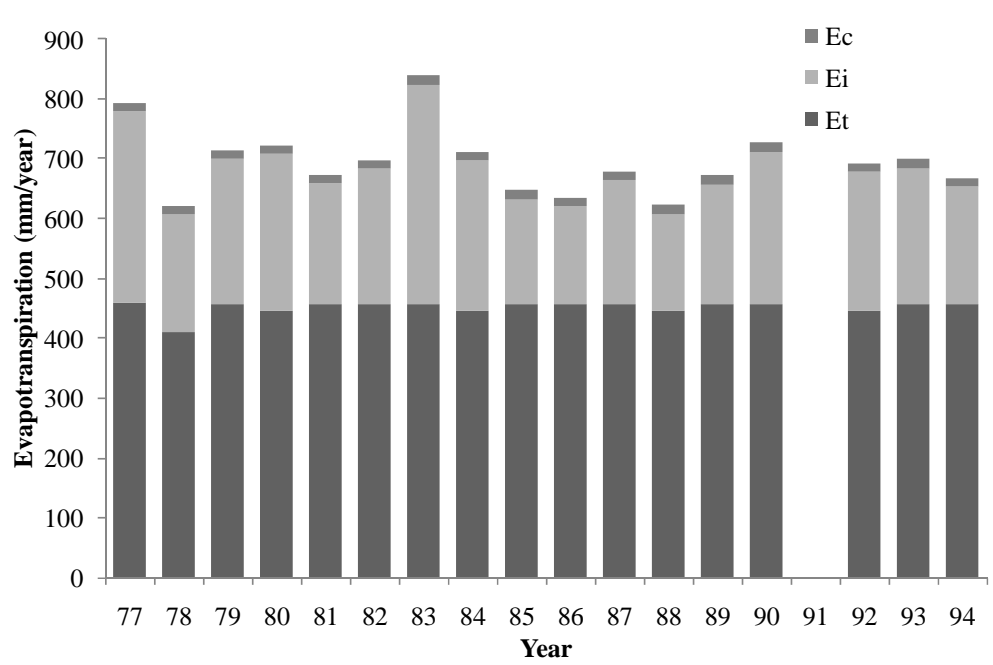

Figure 4. Components variation of evapotranspiration in the period 1977 to 1994 . $\left(E_{t}=\right.$ transpiration, $E_{i}=$ evaporation by interception, $E_{c}=$ evaporation from channel).

From the data of Figures 3 and 4, the ratios of the total discharge and the total evapotranspiration on the annual rainfall are $62 \%$ and $44 \%$, respectively (Table 3 ). The soilwater storage change is $-6 \%$. The mean total discharge of the CSRC is $12.3 \mathrm{~m}^{3} / \mathrm{s}$.

Table 3. Mean annual water balance of the Cubatão-Sul river catchment in the period 1977 to 1994.

\begin{tabular}{lcc}
\hline Component & (mm/year) & (\%) \\
\hline Rainfall $(R)$ & 1563 & 100.0 \\
\hline Total discharge $(Q)$ & 963 & 62 \\
Direct runoff $\left(Q_{d}\right)$ & 253 & 16 \\
Direct runoff from hillslope $\left(Q_{h}\right)$ & 206 & 13 \\
Direct runoff from channel $\left(Q_{c}\right)$ & 47 & 3 \\
Base flow $\left(Q_{b}\right)$ & 710 & 45 \\
\hline Evapotranspiration $(E)$ & 687 & 44 \\
Evaporation through interception $\left(E_{i}\right)$ & 229 & 15 \\
Transpiration $\left(E_{t}\right)$ & 445 & 28 \\
Evaporation from channel $\left(E_{c}\right)$ & 14 & 1 \\
\hline Change of the soil-water storage $(d S)$ & -87 & -6 \\
\hline
\end{tabular}

Figure 5 demonstrates the relationships between total discharge $Q$ and evapotranspiration $E$ to rainfall $P$. The increasing rate of $Q$ over $P$ is larger than that of $E$. In the case that $P$ is larger than $930 \mathrm{~mm} /$ year, approximately, $Q>E$ and, in the opposite scenario, $E$ could be larger than $Q$. 


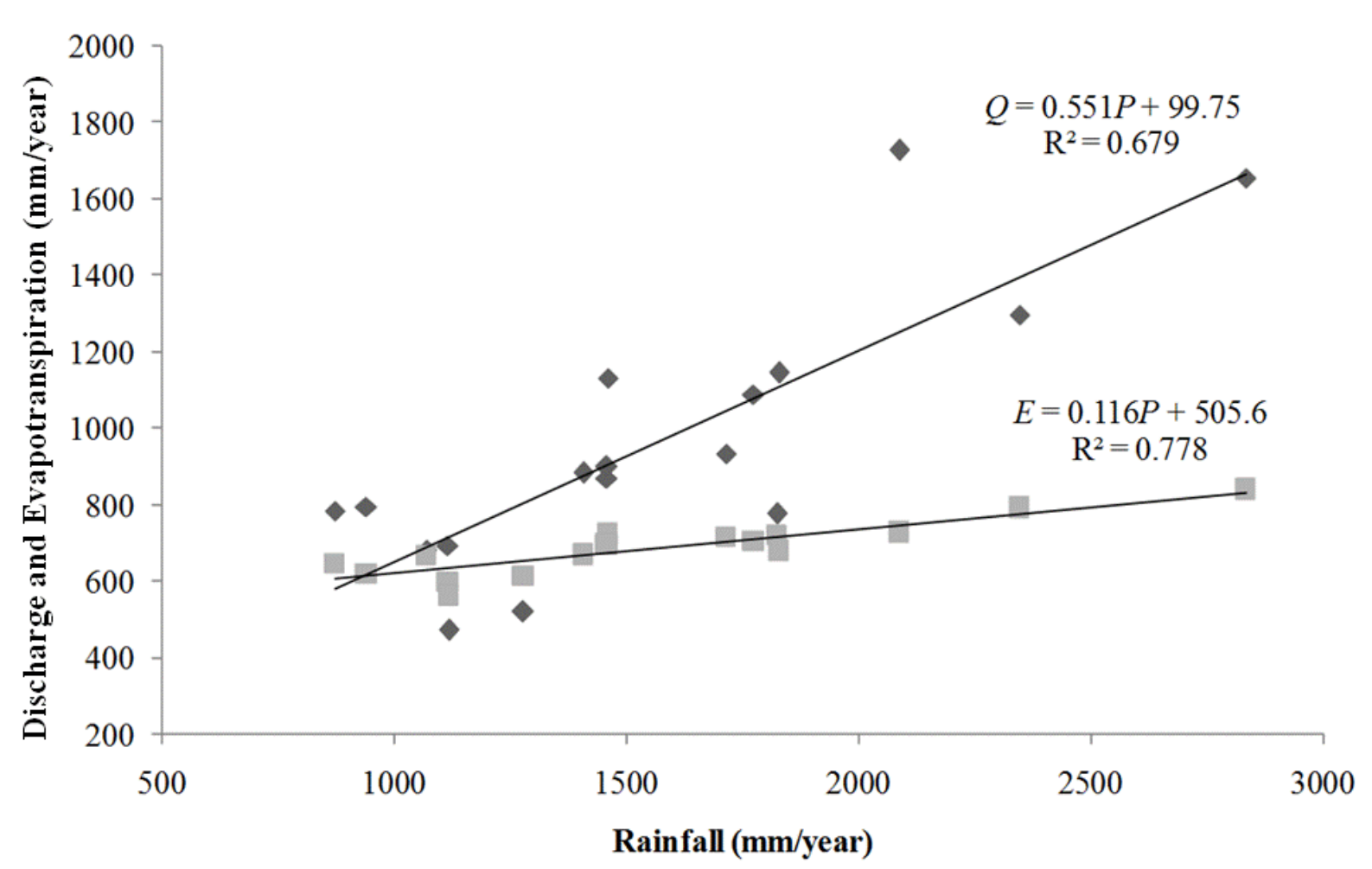

Figure 5. Relationship between discharge and evapotranspiration with rainfall.

\subsection{Annual evapotranspiration}

Table 4 shows the mean values of annual (actual or potential) evapotranspiration for the CSRC calculated using all six methods. According to the data obtained by EPAGRI, the mean annual precipitation in the catchment was $1563 \mathrm{~mm}$ for the study period. This value is smaller than that of the potential evapotranspiration calculated with the Hamon method. In practice, the values of the actual evapotranspiration, estimated with the water budget method and the HYCYMODEL, were the same.

Table 4. Mean annual evapotranspiration of the Cubatão-Sul river catchment for the study period.

\begin{tabular}{ccc}
\hline Method & $E(\mathrm{~mm} /$ year $)$ & $E / P(\%)$ \\
\hline Hamon & $1752^{*}$ & 112 \\
Modified Penman & $1197^{*}$ & 77 \\
Blaney and Criddle & $1058^{*}$ & 68 \\
Thornthwaite & $994^{*}$ & 64 \\
Water budget & $690^{\dagger}$ & 44 \\
HYCYMODEL & $690^{\dagger}$ & 44 \\
\hline
\end{tabular}

$*$ is potential evapotranspiration; ${ }^{\dagger}$ is actual evapotranspiration.

Fujieda et al. (1997) showed that the actual evapotranspiration is $30 \%$ of the annual precipitation in the Serra do Mar, São Paulo State. Compared with this value, the annual evapotranspiration in the CSRC can be considered high. With the values of the evapotranspiration calculated with the water budget method and the HYCYMODEL, the runoff ratio $(F)$, which is defined as the ratio of the annual runoff on the annual rainfall, was calculated as $62 \%$ in the CSRC approximately. 
The annual ratio of the actual evapotranspiration to the potential evapotranspiration calculated with the Hamon method, the modified Penman method, the Blaney and Criddle method, and the Thornthwaite method are 0.39, 0.58, 0.65 and 0.69 , respectively.

\subsection{Monthly evapotranspiration}

Figure 6 shows the change of monthly evapotranspiration calculated by all six methods. The graph patterns obtained with the modified Penman method, the Blaney and Criddle method and the Thornthwaite method are comparatively similar in the period analyzed (Figure 6(b), (c) and (d)). On the other hand, results of Hamon method and water budget method demonstrate high variation patterns (Figure 6 (a) and (e)).
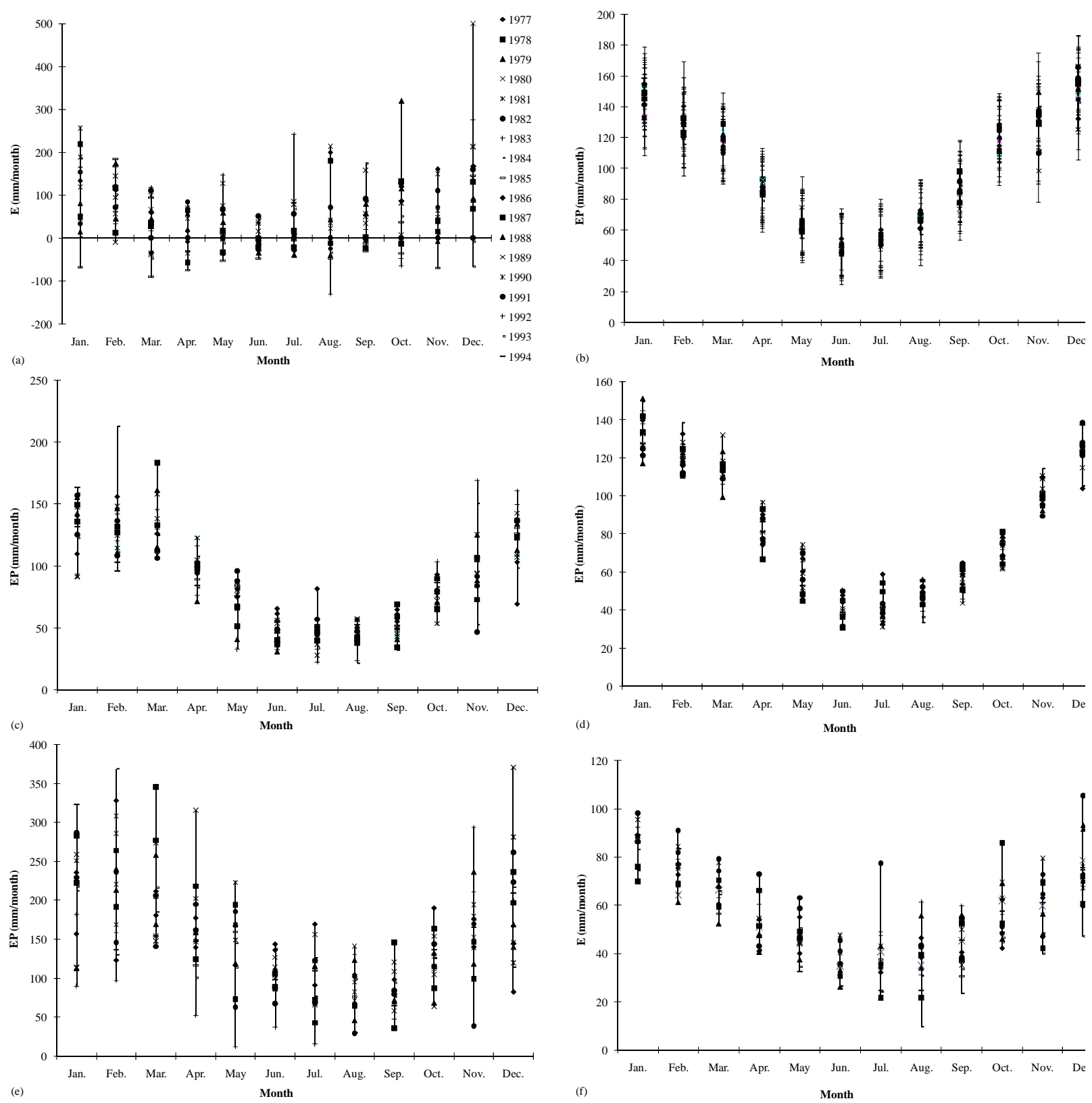

Figure 6. Monthly evapotranspiration of the Cubatão-Sul river catchment during the study period: (a) water budget method; (b) modified Penman method; (c) Blaney and Criddle method; (d) Thornthwaite method; (e) Hamon method; e (f) HYCYMODEL. 
In Figure 6(a) some monthly evapotranspiration values are negative. The occurrence of negative $\mathrm{E}$ values indicates that the monthly water budget method is not adequate for this catchment. That is why mean values were used instead.

The mean monthly evapotranspiration during the study period was calculated with each method. The changes of the mean monthly evapotranspiration obtained with the six methods are graphically shown in Figure 7. The graphs obtained with the Penman modified method, the Blaney and Criddle method and Thornthwaite method have similar patterns. The result with Hamon method is very different from the others. Observing the results of Table 4, it can be stated that Hamon method overestimates the potential evapotranspiration and that it is unrealistic for the CSRC situation.

Figure 7 shows clearly that evapotranspiration rate is highest in the summer. Winter was the season with the lowest monthly evapotranspiration shown by Blaney and Criddle method, Thornthwaite method, Hamon method and HYCYMODEL. Fall shows lower values with the water budget method and modified Penman method.

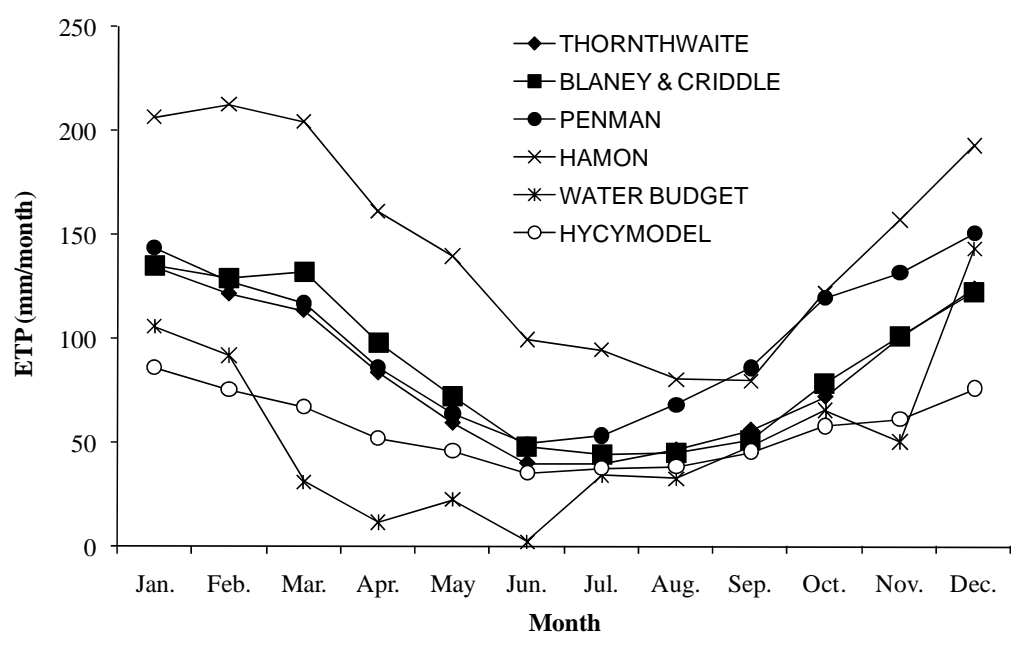

Figure 7. Comparison of mean monthly evapotranspiration change of the Cubatão-Sul river catchment during the study period using six methods.

\section{CONCLUSIONS}

In order to study the annual water balance of the Cubatão-Sul river catchment (403.83 $\mathrm{km}^{2}$ ), Santa Catarina State, Brazil, the data observed at the hydro-meteorological stations during the period 1977-1994 was analyzed with HYCYMODEL proposed by Fukushima (1988). The total discharge and the evapotranspiration are approximately $62 \%$ and $44 \%$ of the total rainfall, respectively. The base flow is about $74 \%$ of the total discharge, which agrees with the data of Hewlett (1982). The high ratio of transpiration to the evapotranspiration implies that, if deforestation occurs in the catchment, the total discharge will strongly increase.

The increasing rate of discharge over rainfall is larger than that of the evapotranspiration. When the annual rainfall is more than $930 \mathrm{~mm}$, the discharge is always larger than the evapotranspiration.

Using six methods (water budget method, Thornthwaite method, Hamon method, modified Penman method, Blaney and Criddle method and the HYCYMODEL), the monthly and annual evapotranspiration in the CSRC during the period 1977-1994 was evaluated. 
Although the annual values of the actual evapotranspiration estimated with the water budget method and the HYCYMODEL were similar, the monthly patterns obtained were different. The values of the ratio of the annual actual evapotranspiration to the annual potential evapotranspiration are 0.39, 0.58, 0.65 and 0.69 for Hamon method, Penman modified method, Blaney and Criddle method and Thornthwaite method, respectively.

The annual potential evapotranspiration value obtained with Hamon method is larger than that of the annual discharge. Therefore, this method is not suitable for this region.

These results will be useful for establishing water resources management strategies and land use guidelines for the Cubatão-Sul watershed.

\section{AKNOWLEDGEMENTS}

The authors are grateful to CNPq for providing a scholarship and Empresa de Pesquisa Agropecuária e Extensão Rural de Santa Catarina S.A. (EPAGRI) for providing hydrometeorological data of the Cubatão-Sul watershed.

\section{REFERENCES}

BRUTSAERT, W.H. Evapotranspiration into the atmosphere. New York: Springer, 1982. 316p.

BLANEY, H. F.; CRIDDLE, W. D. Determining consumptive use for water developments. In: Method for estimating evapotranspiration. New York: ASCE, 1966. p.35-64.

DOORENBOS, J.; PRUITT, W. O. Crop water requirement. Rome: FAO, 1977. 144p.

FUKUSHIMA, Y. A model of river flow forecasting for small forested mountain catchment. Hydrological Processes, Chichester, v. 2, p.167-185, 1988.

FUJIEDA, M.; KUDOH, T.; CICCO, V.; CARVALHO, J. L. Hydrological processes at two subtropical forest catchments: the Serra do Mar, São Paulo, Brazil. Journal of Hydrology, Amsterdam, v. 196, p. 26-46, 1997.

HAMON, W. R. Estimating potential evapotranspiration. Journal of Hydraulics Division ASCE, New York, v. 87 (HY3), p.107-119, 1961.

HEWLETT, J. D. Principles of Forest Hydrology. Athens: The University of Georgia Press, 1982. 183p.

KOBIYAMA, M.; DUARTE, C. Aplicação do modelo HYCYMODEL para análise de chuvavazão da bacia Cubatão-Sul no estado de Santa Catarina. In: BRAZILIAN SYMPOSIUM ON WATER RESOURCES, 12., 16-20 nov. 1997, Vitória, Proceedings... São Paulo: ABRH, 1997. p.589-596.

KOBIYAMA, M.; OLIVEIRA, S. M. Discharge and water quality of the Cubatão river, Santa Catarina State, Brazil. Revista do Setor de Ciências Agrárias UFPR, Curitiba, v. 18, p. 23-28, 1999.

PENMAN, H. L. Natural evaporation from open water, bare soil, and grass. Proceedings of Royal Society of London (Series A), London, v. 193, p. 120-145, 1948.

PEREIRA, A. R.; VILLA NOVA, N. A.; SEDIYAMA, G. C. Evapo(transpi)ração. Piracicaba: FEALQ/ESALQ/USP, 1997. 183p. 
SANTA CATARINA. Atlas de Santa Catarina. Rio de Janeiro: Aerofoto Cruzeiro, 1986.

SILVA, L. D.; BORTOLUZZI, C. A. (eds.) Mapa geológico do estado de Santa Catarina. Florianópolis: Secretaria de Ciência e Tecnologia, Minas e Energia, 1987.

THORNTHWAITE, C. W. An approach toward a rational classification of climate. Geography Review, Washington, v. 38, p. 55-94, 1948.

UNESCO. Guia metodologica para la elaboracion del balance hídrico de América del Sur. Montevideo: UNESCO, 1982. 130p.

VILLELA, S. M.; MATTOS, A. Hidrologia aplicada. São Paulo: McGraw-Hill do Brasil, 1975. 245p. 